\title{
Solidarity in Europe: A Comparative Assessment and Discussion
}

\author{
Christian Labusen and Maria Grasso
}

\section{INTRODUCTION}

Citizens across Europe are committed to solidarity in its various manifestations. As we know from previous studies, almost two-thirds of the population support redistributive policies aimed at reducing income inequalities (Burgoon 2014). Asked about their own commitment in practical terms, every fifth European citizen reports to have donated time or money to non-profit organizations (Bauer et al. 2013), and every third says to have joined an unconventional protest such as signing petitions or boycotting products (Hafner Fink 2012). Overall, the European citizenry cherishes solidarity as a private and public virtue. However, differences between the European people are considerable, particularly when comparing the high levels of voluntary engagement and political participation in Northern Europe with the lower rates in the Mediterranean and Eastern European countries (Anheier and Salamon 1999; Oorschot et al. 2006). Moreover, people tend to differentiate between groups in deciding whom

\section{Lahusen $(\bowtie)$}

Department of Social Sciences, University of Siegen, Siegen, Germany

M. Grasso

Department of Politics, University of Sheffield, Sheffield, UK

(C) The Author(s) 2018

C. Lahusen, M. Grasso (eds.), Solidarity in Europe, Palgrave Studies in European Political Sociology, https://doi.org/10.1007/978-3-319-73335-7_10 
to support. In this respect, they see the elderly and the sick as more deserving than the jobless and the latter as more deserving than immigrants (Oorschot 2000, 2006). Solidarity is thus a complex and multidimensional phenomenon.

The chapters of this book validate these general findings by making use of survey data gathered in the winter of 2016 by a EU-funded project (TransSOL). A significant proportion of the European population supports redistributive policies in order to equalize income levels within society and substantial numbers of citizens are committed to donating money and time to the needy and to participating in political protests in support of people deprived of their rights. Additionally, national studies highlighted also that citizens are not only committed to support people in need within their own country but to engage in acts of solidarity with those living in other European countries and beyond the European continent.

This book focuses on cross-national solidarity and allows for providing a richer account of solidarity in Europe than previous studies have done. Evidence presented in this book not only paints a vivid picture of social solidarity within European countries but also helps to ascertain and demarcate the role of European solidarity within this broader panorama. The findings of the previous chapters enable us to compare levels of solidarity between countries and to identify levels of support toward different target groups such as the disabled, the unemployed, and the refugees/ migrants. Additionally, they also highlight the degree to which citizens are committed to support other fellow Europeans, when compared to the solidarity they exhibit with people living in their own country and outside of Europe.

The previous chapters have presented and discussed country-specific findings, thus highlighting the specificities of each national case. These insights require a comparative assessment and reflection on the project's findings. For this purpose, we will present the evidence gathered through our dataset by means of a direct comparison of country-specific levels of solidarity. In particular, we wish to highlight important manifestations of European solidarity by means of a series of tables describing the extent to which citizens in the eight countries under analysis are committed to practices of solidarity and redistributive policies at EU level. This evidence will be discussed in a concluding section, highlighting the main forces driving European solidarity and the implications of our findings for the future prospects of social cohesion in Europe. 


\section{European Solidarity: A Comparative Panorama}

Our empirical analysis of European solidarity focuses on two manifestations. On the one hand, we deal with interpersonal forms of solidarity by comparing different levels of reported solidarity practices in eight European countries. On the other hand, we focus on the respondents' views on redistributional policies at the national and European level. In both respects, we wish to unveil the motivations and rationales guiding and patterning these forms of solidarity.

In the first step, we direct our attention to interpersonal, social solidarity. Our questionnaire had asked respondents to indicate the kind of activities they have been engaged in support of other people. They could report about a variety of conventional and unconventional activities (Grasso 2011, 2016), specifically the following six items: attended a march/protest/demonstration, donated money or time, bought or refused to buy products, engaged as a passive member or as an active member of an organization. For simplicity reasons, we examined whether citizens showed interpersonal solidarity by engaging in at least one activity.

Table 10.1 summarizes the findings by differentiating the answers of our respondents according to the six target groups of our study. The find-

Table 10.1 Personal support of other people

\begin{tabular}{|c|c|c|c|c|c|c|c|}
\hline & $\begin{array}{c}\text { People } \\
\text { in your } \\
\text { own } \\
\text { country } \\
(\%)\end{array}$ & $\begin{array}{l}\text { People in } \\
\text { other } \\
\text { countries } \\
\text { within the } \\
\text { EU (\%) }\end{array}$ & $\begin{array}{c}\text { People in } \\
\text { countries } \\
\text { outside } \\
\text { the EU } \\
\text { (\%) }\end{array}$ & $\begin{array}{l}\text { Disability } \\
\text { rights (\%) }\end{array}$ & $\begin{array}{c}\text { The } \\
\text { unemployed } \\
(\%)\end{array}$ & $\begin{array}{l}\text { Refugees/ } \\
\text { asylum } \\
\text { seekers } \\
(\%)\end{array}$ & $\begin{array}{l}\text { Total } \\
N\end{array}$ \\
\hline Denmark & 47 & 23 & 35 & 44 & 27 & 30 & 2183 \\
\hline France & 47 & 25 & 30 & 50 & 24 & 20 & 2098 \\
\hline Germany & 51 & 31 & 40 & 52 & 27 & 34 & 2064 \\
\hline Greece & 62 & 35 & 36 & 62 & 58 & 36 & 2061 \\
\hline Italy & 47 & 32 & 33 & 49 & 36 & 28 & 2087 \\
\hline Poland & 59 & 35 & 37 & 65 & 40 & 27 & 2119 \\
\hline UK & 38 & 19 & 25 & 35 & 19 & 22 & 2221 \\
\hline Switzerland & 59 & 34 & 45 & 67 & 33 & 33 & 2083 \\
\hline Total & 51 & 29 & 35 & 53 & 33 & 29 & 16,916 \\
\hline
\end{tabular}

'Have you ever done one of the following in order to support the rights of people/groups? Attend a protest, donate money or time, buy or boycott a product, passive or active membership in an organization' Source: TransSOL (Horizon2020, GA, no. 649435) 
ings show that a considerable number of European citizens report having been engaged in solidarity activities for other people, including donating money or time, protesting and engaging in voluntary associations. Concerning the spatial dimension, we see that practiced solidarity is strongest at the national level and that solidarity with fellow Europeans is lower than the support for people outside the EU. As we will see below, this seems to reflect the attachment of citizens to the various reference groups, because citizens feel most attached to their own country and to humankind, while fewer respondents feel European. At the same time, solidarity is more diffused in regard to disabilities, when compared to the jobless and refugees or migrants. Consequently, our data reflects what we would expect when taking previous studies into consideration (Burgoon 2014; Bauer et al. 2013; Oorschot 2000).

Differences in levels of solidarity emerge when disaggregating the findings according to our eight countries. However, it is interesting to note that these levels of solidarity are more similar than one would expect considering the findings of previous comparative studies (e.g., Bauer et al. 2013; Burgoon 2014). Particularly Greek and Polish citizens (and to a lesser extent also Italians) reported high levels of participation in activities of support toward people within and outside their country, and these rates are close to-or even higher than-the levels of solidarity in the other, supposedly more active countries. This could reflect the situation of crisis, uncertainty and transition experienced in these countries. Particularly in the case of Greece, we know that the economic and financial crisis since 2008 - as well as the refugees crisis of 2015/2016-have unleashed a wave of social solidarity initiatives (Sotiropoulos and Bourikos 2014; Giugni and Grasso 2016; Grasso and Giugni 2016). But also in other countries, the support for refugees and asylum seekers is rather high, when remembering that previous studies see these target groups far behind other potential recipients (e.g., Oorschot 2000, 2006). This observation applies to Denmark, Germany, Greece and Switzerland. The dramatic hardship experienced by refugees on their way to and through Europe to their countries of destination incited a wave of 'welcoming' initiatives in these countries (Evangelinidis 2016). In this sense, our data reveals that European citizens tend to deliver in terms of voluntary engagement in time of crisis and emergency situations.

In the second step, we move to another manifestation of solidarity, namely, public support for policies of redistribution and burden sharing. Table 10.2 gives us a first impression by summarizing the findings 
Table 10.2 Eliminating inequalities

\begin{tabular}{lllllll}
\hline & $\begin{array}{l}\text { Not at all } \\
\text { important } \\
(\%)\end{array}$ & $\begin{array}{l}\text { Not very } \\
\text { important } \\
(\%)\end{array}$ & $\begin{array}{l}\text { Neither } \\
(\%)\end{array}$ & $\begin{array}{l}\text { Fairly } \\
\text { important } \\
(\%)\end{array}$ & $\begin{array}{l}\text { Very } \\
\text { important } \\
(\%)\end{array}$ & Total N \\
\hline Denmark & 5.4 & 12.7 & 33.1 & 32.8 & 16 & 2183 \\
France & 2.4 & 5.8 & 20.3 & 37.5 & 34 & 2098 \\
Germany & 2 & 6.2 & 22.8 & 39.3 & 29.7 & 2064 \\
Greece & 1.8 & 3.5 & 16.7 & 35.1 & 42.9 & 2061 \\
Italy & 1.4 & 3 & 14.9 & 40 & 40.7 & 2087 \\
Poland & 2.6 & 5.4 & 21.7 & 36.5 & 33.8 & 2119 \\
UK & 3.6 & 6.7 & 28.5 & 35.8 & 25.4 & 2083 \\
Switzerland & 3.2 & 7.9 & 22.3 & 38.9 & 27.7 & 2221 \\
Total & 2.8 & 6.5 & 22.6 & 37.0 & 31.1 & 16,916 \\
\hline
\end{tabular}

'In order to be considered fair, what should a society provide? Eliminating big inequalities in income between citizens'

Source: TransSOL (Horizon2020, GA, no. 649435)

of a question measuring the general disposition of citizens to support a fair distribution of wealth. We see that every third respondent agrees that the goal of eliminating big inequalities is 'very important' and the proportion increases to more than two-thirds of the population when adding those who view this as 'fairly important'. Differences between the eight countries are very pronounced and reflect what we know from other studies about the support of redistributive policies within countries (Svallfors 1997; Blekesaune and Quadagno 2003; Burgoon 2014; Grasso et al. 2017). A complex set of factors plays a role, among them the level of prevailing inequalities, the standards of redistribution already in place, predominant political orientations and values.

For our own purposes, however, it is more telling to look at the differences in public support for redistribution at the global and European level. Table 10.3 presents the evidence in regard to the global scope of redistribution. Respondents were asked to indicate how important it should be for the EU to help people in developing countries. A strong majority of respondents supports the attempts of the EU to help countries outside of Europe in fighting poverty and promoting development, with $62 \%$ supporting and only $14 \%$ opposing these measures. Even though the biggest share thinks that this global commitment is only fairly important, every fifth respondent indicated that this engagement is very important. 
Table 10.3 Development aid

\begin{tabular}{lcccccc}
\hline & $\begin{array}{c}\text { Not at } \\
\text { all }(\%)\end{array}$ & $\begin{array}{c}\text { Not very } \\
(\%)\end{array}$ & $\begin{array}{c}\text { Neither } \\
(\%)\end{array}$ & $\begin{array}{c}\text { Fairly } \\
\text { important (\%) }\end{array}$ & $\begin{array}{c}\text { Very important } \\
(\%)\end{array}$ & $\begin{array}{l}\text { Total } \\
\text { (\%) }\end{array}$ \\
\hline Denmark & 4 & 8 & 26 & 43 & 19 & 2183 \\
France & 5 & 9 & 32 & 38 & 16 & 2098 \\
Germany & 3 & 6 & 18 & 46 & 28 & 2064 \\
Greece & 6 & 7 & 21 & 44 & 22 & 2061 \\
Italy & 4 & 7 & 18 & 46 & 26 & 2087 \\
Poland & 5 & 16 & 35 & 35 & 8 & 2119 \\
United & 6 & 9 & 27 & 37 & 21 & 2083 \\
Kingdom & & & & & & \\
Switzerland & 3 & 8 & 20 & 44 & 25 & 2221 \\
Total & 5 & 9 & 25 & 42 & 20 & 16,916 \\
\hline
\end{tabular}

'The European Union provides development aid to assist certain countries outside the EU in their fight against poverty and in their development. How important do you think it is to help people in developing countries?’

Source: TransSOL (Horizon2020, GA, no. 649435)

When we move to the European level, we see that public support for EU-internal help is much more limited, particularly if specific measures of redistribution and burden sharing are at stake. Our questionnaire listed two questions that aimed at measuring redistributional preferences. On the one hand, we asked respondents whether they support the EU in pooling funds to help EU countries having difficulties in paying their debts. On the other hand, we wanted to know whether respondents agree to grant the EU with more funds in order to help refugees. In regard to Switzerland, respondents answered in a more hypothetical manner, but their responses are not very different to those of EU citizens. For the other countries, the picture is rather mixed.

In regard to fiscal solidarity between member states, the supporters outweigh the opponents only slightly (41\% vs. $30 \%$ ), with $29 \%$ undecided respondents (see Table 10.4). The biggest group of supporters are located in Italy (66\% against 16\% opponents) and Greece (64\% vs. 11\%). Poland leans more toward the helping side (39\% vs. $20 \%)$, but this is also due to the number of undecided respondents. In Denmark, Germany and the United Kingdom the share of opponents is bigger than the group of supporters, with $38 \%$ versus $28 \%$, $41 \%$ versus $33 \%$ and $41 \%$ versus $34 \%$. These findings show that countries on the giving and receiving side stress differently the idea of fiscal solidarity. While the population in countries that 
Table 10.4 Fiscal solidarity: pay public debts

\begin{tabular}{lcccccc}
\hline & $\begin{array}{c}\text { Strongly } \\
\text { disagree }(\%)\end{array}$ & $\begin{array}{c}\text { Disagree } \\
(\%)\end{array}$ & $\begin{array}{c}\text { Neither } \\
(\%)\end{array}$ & $\begin{array}{c}\text { Agree } \\
(\%)\end{array}$ & $\begin{array}{c}\text { Strongly agree } \\
(\%)\end{array}$ & $\begin{array}{c}\text { Total } \\
N\end{array}$ \\
\hline Denmark & 14 & 24 & 34 & 23 & 5 & 1939 \\
France & 15 & 19 & 30 & 28 & 8 & 1903 \\
Germany & 15 & 26 & 25 & 27 & 6 & 1914 \\
Greece & 7 & 4 & 24 & 38 & 26 & 1975 \\
Italy & 5 & 11 & 18 & 47 & 19 & 1928 \\
Poland & 8 & 12 & 42 & 33 & 6 & 1938 \\
United & 18 & 23 & 25 & 27 & 7 & 1861 \\
Kingdom & & & & & & \\
Switzerland & 14 & 22 & 31 & 28 & 5 & 1992 \\
Total & 12 & 18 & 29 & 31 & 10 & 15,455 \\
\hline
\end{tabular}

'The EU is currently pooling funds to help EU countries having difficulties in paying their debts. To what extent do you agree or disagree with this measure?'

Source: TransSOL (Horizon2020, GA, no. 649435)

have mastered the financial and economic crisis are more skeptical toward measures of fiscal solidarity, the countries affected more strongly by these crises tend to stress more overtly the fact that EU member states should conform to one of their values, namely, interstate help and solidarity. This contrast is even more evident when considering that the share of respondents fully agreeing with measures of fiscal solidarity is very low everywhere, with an exception of Italy and Greece.

In regard to EU funds in support of refugees, we find very similar results. Table 10.5 shows that the group opposing more funds for EU measures slightly outweighs the supporters (39\% vs. $35 \%)$, again with a considerable share of undecided respondents. Supporters of this measure are more numerous in Germany (47\%), Denmark (41\%) and Greece (39\%), while least diffused in France, (26\%), Italy (27\%) and Poland (29\%). Again, those countries faced with higher rates of forced migrants and thus more dependent on European solidarity are those calling for more financial help from all member states. Before this backdrop, it comes as no surprise that the Danish, the Germans and the British are among those 'strongly supporting' this redistribution.

These findings highlight that public support for at least some kinds of EU-internal solidarity measures is rather moderate. However, there are important reasons we should abstain from comparing this modest support directly with the more extended endorsement of humanitarian aid for 
Table 10.5 Fiscal solidarity: help refugees

\begin{tabular}{lcccccc}
\hline & $\begin{array}{c}\text { Strongly } \\
\text { oppose (\%) }\end{array}$ & $\begin{array}{c}\text { Somewhat } \\
\text { oppose }(\%)\end{array}$ & $\begin{array}{c}\text { Neither } \\
(\%)\end{array}$ & $\begin{array}{c}\text { Somewhat } \\
\text { support (\%) }\end{array}$ & $\begin{array}{c}\text { Strongly } \\
\text { support (\%) }\end{array}$ & $\begin{array}{l}\text { Total } \\
N\end{array}$ \\
\hline Denmark & 16 & 17 & 25 & 27 & 14 & 2183 \\
France & 26 & 19 & 29 & 21 & 5 & 2098 \\
Germany & 12 & 17 & 24 & 35 & 12 & 2064 \\
Greece & 24 & 15 & 23 & 31 & 8 & 2061 \\
Italy & 21 & 25 & 28 & 23 & 4 & 2087 \\
Poland & 18 & 19 & 33 & 24 & 5 & 2119 \\
United & 20 & 18 & 27 & 26 & 10 & 2221 \\
Kingdom & & & & & & \\
Switzerland & 21 & 25 & 20 & 28 & 6 & 2083 \\
Total & 20 & 19 & 26 & 27 & 8 & 16,916 \\
\hline
\end{tabular}

'Would you support or oppose your country's government offering financial support to the European Union in order to help refugees?'

Source: TransSOL (Horizon2020, GA, no. 649435)

developing countries. Measures of fiscal solidarity within the EU imply a more far-reaching commitment of member states than humanitarian aid. In fact, the magnitude and the implications of EU-internal fiscal solidarity seem to provide reasons for why public support might be more modest and for why the share of citizens fully agreeing with EU-internal measures of solidarity is lower. Among other factors, we need to consider that many policy areas within the EU are patterned by the idea of subsidiarity, and this means that nation-states take the responsibility for problem solving. The moderate support for EU-internal solidarity in some respects is thus to be taken for what it is: citizens are less enthusiastic about authorizing their governments to help other EU member states' governments in solving the problems with their debt and refugees.

The moderate support for measures of fiscal solidarity raises the question of what motivates respondents to be more cautious. An answer is provided by a question included into our survey. It asked respondents to specify the potential reasons for granting or denying fiscal support to other EU countries. The results presented in Table 10.6 show that fiscal solidarity is conditional and seems to privilege reciprocity. In fact, our respondents are not ready to support other EU countries in trouble unconditionally. Only a minority of $19 \%$ testifies that fiscal solidarity is a matter of moral duty. The largest group subscribes to the idea of reciprocity, fairness, trustworthiness and deservingness (see Lengfeld et al. 2015; 
Table 10.6 Fiscal solidarity: reasons

\begin{tabular}{|c|c|c|c|c|c|c|c|c|c|}
\hline & Denmark & France & Germany & Greece & Italy & Poland & $U K$ & $\mathrm{CH}$ & Total \\
\hline $\begin{array}{l}\text { Financial } \\
\text { help has also } \\
\text { beneficial } \\
\text { effects for } \\
\text { the own } \\
\text { country }\end{array}$ & 20 & 13 & 15 & 19 & 16 & 24 & 15 & 13 & 17 \\
\hline $\begin{array}{l}\text { It is our } \\
\text { moral duty } \\
\text { to help other } \\
\text { member } \\
\text { states that } \\
\text { are in need }\end{array}$ & 18 & 16 & 21 & 27 & 20 & 20 & 17 & 15 & 19 \\
\hline $\begin{array}{l}\text { Member } \\
\text { states should } \\
\text { help each } \\
\text { other, as } \\
\text { somewhere } \\
\text { along the } \\
\text { way every } \\
\text { country may } \\
\text { require help }\end{array}$ & 33 & 37 & 45 & 59 & 52 & 49 & 31 & 42 & 44 \\
\hline $\begin{array}{l}\text { Financial } \\
\text { help should } \\
\text { not be given } \\
\text { to countries } \\
\text { that have } \\
\text { proven to } \\
\text { handle } \\
\text { money badly }\end{array}$ & 40 & 37 & 40 & 22 & 26 & 38 & 42 & 38 & 35 \\
\hline Don't know & 19 & 17 & 9 & 8 & 13 & 11 & 16 & 12 & 13 \\
\hline Total $N$ & 2183 & 2098 & 2064 & 2061 & 2087 & 2119 & 2083 & 2221 & 16,916 \\
\hline
\end{tabular}

'There are many reasons to state for or against financial help for EU countries in trouble. Which one of the following best reflects how you feel?' Multiple answers possible (in \%)

Source: TransSOL (Horizon2020, GA, no. 649435)

also Wheeless 1978; Thielemann 2003). Fiscal solidarity is a matter of giving and receiving for almost every second respondent, and one out of three citizens thinks that help should be given only to those countries that handle help responsibly. While countries diverge in the extent to which they subscribe to these statements, there is no doubt that both 
considerations are the most widely shared forms of reasoning everywhere. Accordingly, European solidarity suffers immediately, when citizens have the feeling that support measures are one-sided and potentially misused. Interestingly enough, citizens' judgments about fiscal solidarity within the EU do not seem to be very different to what we know about public norms guiding public support of redistribution within national welfare states (Bowles and Gintis 2000; Oorschot 2006; León 2012).

\section{Solidarity With Non-EU Citizens: AtTitudes Toward Migration and the Inclusion of Migrants}

Migration policies have become a highly salient issue within the public sphere (Green-Pedersen and Otjes 2017). The growing inflows of forced migrants from the Middle East during the summer of 2015 have certainly contributed to this development. In particular, it has put the topic of European solidarity on the public agenda. In the previous section, we showed that almost every third respondent had been engaged in practices of support for migrants, especially in those countries that were on the migration routes of refugees and were confronted with a bigger need. But what can we say about policy preferences? Do citizens support immigration policies that welcome refugees within their country, and do they approve also of European policies of 'burden sharing'? These aspects are important for our analytic purposes. Citizens' attitudes toward immigration and immigration policies are an important indicator of the society's openness toward non-nationals and thus also for the inclusivity of solidarity. For this reason, we included a series of questions in our survey that were geared towards measuring public attitudes toward policies addressing groups migrating into one's country from the EU and from outside of it. A particular focus in this respect were Syrian refugees fleeing their war-torn country.

Table 10.7 looks first at respondent opinions in terms of the types of measures they think their government should pursue in terms of economic migrants from within the European Union. As we can see, across countries most people tend to accept economic migration in so far as 'there are jobs they can do'. Lower proportions are more liberal agreeing to 'allow all those who want to come'. In particular, Greeks and Poles tend to be the most welcoming followed by Italians and Germans and Danes, then the French with the Brits and the Swiss being the least welcoming with only $10 \%$ selecting this option. Indeed, the Brits and Swiss display the highest 
Table 10.7 Immigration policies for EU citizens (in \%)

\begin{tabular}{lcccccc}
\hline & $\begin{array}{c}\text { Allow in } \\
\text { all those } \\
\text { who want } \\
\text { to come }\end{array}$ & $\begin{array}{c}\text { Allow people to } \\
\text { come as long as } \\
\text { there are jobs } \\
\text { they can do }\end{array}$ & $\begin{array}{c}\text { Put strict } \\
\text { limits on the } \\
\text { number } \\
\text { allowed to } \\
\text { come }\end{array}$ & $\begin{array}{c}\text { Probibit people } \\
\text { from these } \\
\text { countries } \\
\text { coming here }\end{array}$ & $\begin{array}{c}\text { Don't } \\
k n o w\end{array}$ & Total \\
\hline Denmark & 14.6 & 52.1 & 18.9 & 3.8 & 10.7 & 100 \\
France & 13.0 & 42.2 & 25.1 & 8.1 & 11.6 & 100 \\
Germany & 16.3 & 46.2 & 26.1 & 4.8 & 6.7 & 100 \\
Greece & 22.0 & 44.7 & 23.0 & 4.2 & 6.1 & 100 \\
Italy & 16.7 & 48.5 & 20.7 & 5.7 & 8.3 & 100 \\
Poland & 20.0 & 44.2 & 19.1 & 5.3 & 11.5 & 100 \\
Switzerland & 7.2 & 46.4 & 36.8 & 4.2 & 5.4 & 100 \\
United & 9.7 & 41.2 & 31.8 & 8.0 & 9.4 & 100 \\
Kingdom & & & & & & \\
Total & 14.9 & 45.7 & 25.2 & 5.5 & 8.7 & 100 \\
\hline
\end{tabular}

'For each of the following groups, what measures do you think the government should pursue? People from European Union coming to ***COUNTRY*** to work?"

Source: TransSOL (Horizon2020, GA, no. 649435)

proportions of respondents agreeing that there should be 'strict limits on the number allowed to come'. Up to $8 \%$ of individuals in the UK would completely prohibit economic migration from the EU $(8.1 \%$ also in France).

The same question was put to respondents in relation to non-EU citizens, too, in order to get a sense of what the impact of EU citizenship might be. Table 10.8 presents these results, which show that people are considerably less welcoming across countries compared to the results for EU migrants presented in Table 10.6. The most welcoming are Italians with about $8 \%$ suggesting all the people who want to come should come, followed by $7.8 \%$ of Greeks, $7 \%$ of Germans, $6.2 \%$ in France and Poland, $5.6 \%$ in Denmark, $5.3 \%$ in the UK and only $4.5 \%$ in Switzerland. In Denmark, Italy, Greece and Poland respondents are more likely to support economic migration provided there are jobs; whereas, in France, Germany, Switzerland and the UK respondents are more likely to prefer putting 'strict limits on the number allowed to come' from non-EU countries. Up to $14.5 \%$ of people in France want to completely prohibit non-EU people from coming to their country, followed by $12.3 \%$ of Germans and about $9-10 \%$ in the other nations adopting this very unforgiving position on migration. 
Table 10.8 Immigration policies for non-EU citizens (in \%)

\begin{tabular}{lcccccc}
\hline & $\begin{array}{c}\text { Allow in } \\
\text { all those } \\
\text { who want } \\
\text { to come }\end{array}$ & $\begin{array}{c}\text { Allow people to } \\
\text { come as long as } \\
\text { there are jobs } \\
\text { they can do }\end{array}$ & $\begin{array}{c}\text { Putstrict } \\
\text { limits on the } \\
\text { number } \\
\text { allowed to } \\
\text { come }\end{array}$ & $\begin{array}{c}\text { Probibit people } \\
\text { from these } \\
\text { countries } \\
\text { coming here }\end{array}$ & $\begin{array}{c}\text { Don't } \\
k n o w\end{array}$ & Total \\
\hline Denmark & 5.6 & 40.3 & 31.8 & 10.7 & 11.6 & 100 \\
France & 6.2 & 32.8 & 34.3 & 14.5 & 12.2 & 100 \\
Germany & 7.0 & 32.1 & 40.3 & 12.3 & 8.3 & 100 \\
Greece & 7.8 & 38.0 & 37.2 & 11.1 & 5.9 & 100 \\
Italy & 8.0 & 46.6 & 27.4 & 9.3 & 8.8 & 100 \\
Poland & 6.2 & 34.8 & 33.7 & 11.9 & 13.4 & 100 \\
Switzerland & 4.5 & 35.3 & 45.1 & 9.2 & 5.8 & 100 \\
UK & 5.3 & 37.0 & 37.2 & 10.5 & 10.0 & 100 \\
Total & 6.3 & 37.1 & 35.9 & 11.2 & 9.5 & 100 \\
\hline
\end{tabular}

'For each of the following groups, what measures do you think the government should pursue? People from non-EU countries coming to ***COUNTRY*** to work?'

Source: TransSOL (Horizon2020, GA, no. 649435)

These findings raise the question of how strong the support for immigration is in regard to Syrian refugees, given that forced migration due to war was very high during the years 2015 and 2016 and underlined much of the public debates about immigration policies. Table 10.9 summarizes the answers to the question of whether Syrian refugees should be treated differently than the two more general groups discussed previously. Here the UK, Denmark and Switzerland stand out as the countries more likely to say higher numbers should be admitted. In most countries however, the largest proportions of citizens prefer either keeping the current numbers or admitting even lower numbers (the latter is particularly true in Greece and Italy). In Poland $36.3 \%$ argued that none should be allowed to come at all, followed by France with $25 \%$ taking this harsh position, $22 \%$ in Italy, $20 \%$ in the UK, around $17 \%$ in Denmark and Greece and 12-13\% in Germany and Switzerland. The latter results show that these citizens have more restrictive preferences when refugees from Syria are concerned, as compared to the other two groups, that is, non-EU citizens and EU citizens. However, the fact that the general population seems to be more cautious about admitting Syrian refugees should not lead us to believe that solidarity is merely ethnically patterned. In fact, our questions addressed the preferred numbers of admitted migrants. The fact that respondents are more restrictive toward Syrian refugees might 
Table 10.9 Immigration policies for Syrian refugees (in \%)

\begin{tabular}{lccccr}
\hline & $\begin{array}{c}\text { Admit higher } \\
\text { numbers }\end{array}$ & $\begin{array}{c}\text { Keep numbers } \\
\text { coming about the } \\
\text { same }\end{array}$ & $\begin{array}{c}\text { Admit lower } \\
\text { numbers }\end{array}$ & $\begin{array}{c}\text { Should not let } \\
\text { any come in }\end{array}$ & $\begin{array}{c}\text { Don't } \\
\text { know }\end{array}$ \\
\hline Denmark & 17.1 & 29.0 & 27.0 & 16.8 & 10.1 \\
France & 10.0 & 21.1 & 29.8 & 25.0 & 14.1 \\
Germany & 9.3 & 35.8 & 37.0 & 12.7 & 5.3 \\
Greece & 8.6 & 18.9 & 49.5 & 16.9 & 6.1 \\
Italy & 8.7 & 23.4 & 34.8 & 22.0 & 11.1 \\
Poland & 9.2 & 24.5 & 15.8 & 36.3 & 14.2 \\
Switzerland & 15.6 & 38.0 & 27.3 & 12.2 & 7.0 \\
UK & 18.1 & 24.9 & 24.8 & 20.0 & 12.3 \\
Total & 12.1 & 27.0 & 30.6 & 20.2 & 10.0 \\
\hline
\end{tabular}

'How do you think your country should handle refugees fleeing the war in Syria?' Source: TransSOL (Horizon2020, GA, no. 649435)

be conditioned by the higher number of migrants coming from these areas in the year preceding our survey and thus by considerations about the capacity of the respondents' countries to integrate them. As we have seen from previous tables, the support for immigration policies is conditional on respondents' views of the capabilities of the situation of the labor market, that is, one could conceive, on the ability to give migrants available job opportunities within the country. These findings converge with previous research in showing that the economic context matters when immigration policies are concerned. The economic strain perceived by citizens has a direct effect on the preferences for how restrictive immigration policies should be but also for the perceptions of ethnic threat that could be seen to fuel calls for restrictive measures, too (Gang et al. 2013; Setten et al. 2017).

These observations illustrate that conditionality is also at stake when solidarity with non-EU citizens is concerned. Our questionnaire included one item that aimed to measure this conditionality by asking respondents about the conditions under which migrants should gain access to social benefits. Table 10.10 shows that only a minority of $12 \%$ is against granting migrants access to social benefits and services categorically. Access is generally concevied as being conditional on two things: they should have worked and paid taxes (42\%), and they should become citizens of the country (30\%). A minority of respondents (16\%) is more generous, granting migrants access unconditionally or after a limited time of residence. In this sense, findings tend to indicate that for most citizens, solidarity is understood as rights-based and 
Table 10.10 Migrants and social rights

\begin{tabular}{lcccccc}
\hline & $\begin{array}{c}\text { Immediately } \\
\text { on arrival } \\
(\%)\end{array}$ & $\begin{array}{c}\text { After living } \\
\text { 1 year (worked } \\
\text { or not) }(\%)\end{array}$ & $\begin{array}{c}\text { After worked } \\
\text { and paid } \\
\text { taxes 1 year } \\
(\%)\end{array}$ & $\begin{array}{c}\text { After } \\
\text { citizenship } \\
(\%)\end{array}$ & $\begin{array}{c}\text { Never } \\
(\%)\end{array}$ & $\begin{array}{c}\text { Total } \\
N\end{array}$ \\
\hline Denmark & 7 & 9 & 37 & 36 & 11 & 2183 \\
France & 5 & 9 & 41 & 26 & 18 & 2098 \\
Germany & 9 & 13 & 46 & 24 & 7 & 2064 \\
Greece & 8 & 8 & 34 & 35 & 15 & 2061 \\
Italy & 8 & 7 & 38 & 36 & 12 & 2087 \\
Poland & 7 & 8 & 43 & 32 & 10 & 2119 \\
UK & 6 & 8 & 46 & 27 & 14 & 2083 \\
Switzerland & 6 & 9 & 52 & 23 & 10 & 2221 \\
Total & 7 & 9 & 42 & 30 & 12 & 16,916 \\
\hline
\end{tabular}

'When should migrants obtain rights to social benefits and services as citizens do?'

Source: TransSOL (Horizon2020, GA, no. 649435)

thus tied to some notion of citizenship, that is, delimited by legal entitlements and mutual obligations (e.g., receiving social benefits and paying taxes or contributions). As such, this suggests that public policies furthering the active participation of migrants in the labor force and their naturalization could be beneficial to further support with respect to the norms of redistributional solidarity echoed in our data.

\section{European Union Membership and Attachment: CORRElates of Solidarity?}

The findings discussed above have provided indications that Europe is a potential frame of reference impacting on the readiness of citizens to support others. Solidarity might thus be intricately tied to feelings of satisfaction and belongingness with regards to the EU. In conceptual terms, we assume that solidarity as a relation of (mutual) support is tied to (imagined) groups, which means that feelings of identity and belongingness should promote the individual's readiness to engage in solidarity with members of these groups (Hunt and Benford 2004; Stets and McCaffree 2014). At the same time, levels of satisfaction with the EU might condition the readiness to help other European and/or European governments, as well. A closer inspection of these factors is important, because they might help to explain the moderate rates of solidarity with other European 
people and countries unveiled at least with respect to certain indicators from our previous analyses. Indeed, the more moderate rates of European solidarity could be conditioned by lower rates of identification and satisfaction with the EU. In order to validate these assumptions, we need to take a closer look at these public attitudes and attachments toward the EU.

The satisfaction with the EU relates to more cognitive and instrumental considerations and motivations. Along these lines, we included a series of questions in our survey that encouraged respondents to evaluate the EU membership of their country, following the example of previous studies (Anderson and Reichert 1996; Hooghe and Marks 2007; Guerra and McLaren 2016). It is to be expected that EU-skeptic attitudes will go hand in hand with a lower disposition to act in solidarity with other European people. Citizens might be more cautious to support measures of European solidarity if they believe that the EU works badly. Hence, it is crucial to know how widely diffused is a negative assessment of the EU.

Table 10.11 presents results from respondents on whether they feel that on balance their country's membership of the EU was good, bad or neither a good nor a bad thing. In Switzerland, we asked about potentially joining the EU. Reflecting once more the patterns found previously, the Swiss think joining the EU would be bad, and the Greeks think that being members of the EU is a bad thing. All the others think it is on balance a good thing, but the gap is smaller in the UK, Italy and France than in Denmark and particularly Germany and Poland.

Table 10.11 EU membership good/bad (in \%)

\begin{tabular}{lccccc}
\hline & Agood thing & A bad thing & Neither good nor bad & Don't know & Total \\
\hline Denmark & 38.9 & 25.3 & 26.3 & 9.6 & 100 \\
France & 34.4 & 26.5 & 29.8 & 9.3 & 100 \\
Germany & 53.3 & 15.6 & 26.6 & 4.5 & 100 \\
Greece & 30.7 & 34.0 & 31.1 & 4.2 & 100 \\
Italy & 35.8 & 30.6 & 26.4 & 7.2 & 100 \\
Poland & 62.7 & 9.2 & 20.9 & 7.2 & 100 \\
Switzerland $^{\mathrm{a}}$ & $8.0^{\mathrm{a}}$ & $67.6^{\mathrm{a}}$ & $18.1^{\mathrm{a}}$ & $6.3^{\mathrm{a}}$ & 100 \\
UK $_{\text {Total }}^{40.3}$ & 35.4 & 18.0 & 6.4 & 100 \\
\hline
\end{tabular}

'Generally speaking, do you think that your country's membership of the European Union is ...?'

Source: TransSOL (Horizon2020, GA, no. 649435)

${ }^{a}$ In Switzerland we asked about joining the EU (joining the EU would be...) 
This evaluation could be tied to a more rational calculation about the advantages and disadvantages of EU membership. For this reason, we added a question asking respondents if they think their country has more directly benefited from being a member of the EU (in Switzerland we asked if they benefited from not being members). Table 10.12 presents the results. In Switzerland, over 70\% think the country has benefited from not being part of the EU. In Greece, in Italy and-by a tiny margin-in France, higher proportions think the country has not benefited from membership. Even in the UK, a higher percentage felt they benefited from membership. In Denmark, Germany and Poland, again attitudes are very positive in terms of feeling that the countries benefited from being part of the EU.

Next to these more general evaluations of EU membership, we also asked respondents to assess the situation of the labor market, if the country were to be outside of the EU. As Table 10.13 shows, respondents had more difficulties here in giving clear indications. Overall, the proportion of respondents who believe that not being a member is detrimental for the labor market is higher when compared to those who say that the number of jobs would increase outside the EU. This is particularly true for Germany and Poland, in part also for Denmark and Italy. More Greek people believe that the labor market would perform better outside the EU. And the Swiss are convinced that a membership would have bad effects on the labor mar-

Table 10.12 Benefited from EU membership (in \%)

\begin{tabular}{lcccc}
\hline & Benefited & Not benefited & Don't know & Total \\
\hline Denmark & 48.6 & 29.8 & 21.7 & 100 \\
France & 36.2 & 37.6 & 26.2 & 100 \\
Germany & 58.5 & 27.4 & 14.2 & 100 \\
Greece & 37.2 & 53.1 & 9.6 & 100 \\
Italy & 28.2 & 52.7 & 19.1 & 100 \\
Poland & 70.9 & 14.3 & 14.8 & 100 \\
Switzerland & $70.3^{\mathrm{a}}$ & $13.4^{\mathrm{a}}$ & $16.3^{\mathrm{a}}$ & 100 \\
UK & 43.7 & 37.0 & 19.3 & 100 \\
Total & 49.4 & 32.9 & 17.7 & 100 \\
\hline
\end{tabular}

'Taking everything into account, would you say that your country has on balance benefited or not from being a member of the European Union?'

Source: TransSOL (Horizon2020, GA, no. 649435)

${ }^{a}$ In Switzerland we asked if the country benefited or not from NOT being a member of the European Union 
Table 10.13 Effect on jobs and employment if country was *outside * the EU (in \%)

\begin{tabular}{lccccc}
\hline & Would be good & Would be bad & Would make no difference & Don't know & Total \\
\hline Denmark & 16.2 & 37.8 & 21.7 & 24.3 & 100 \\
France & 23.8 & 27.6 & 27.8 & 20.8 & 100 \\
Germany & 14.4 & 43.7 & 26.5 & 15.4 & 100 \\
Greece & 38.4 & 31.2 & 16.5 & 14.0 & 100 \\
Italy & 25.9 & 35.4 & 21.9 & 16.8 & 100 \\
Poland & 10.6 & 52.1 & 18.1 & 19.2 & 100 \\
Switzerland & $11.3^{\mathrm{a}}$ & $49.6^{\mathrm{a}}$ & $25.0^{\mathrm{a}}$ & $14.1^{\mathrm{a}}$ & 100 \\
UK $_{\text {Total }}$ & 26.5 & 33.0 & 24.3 & 16.1 & 100 \\
\hline
\end{tabular}

Source: TransSOL (Horizon2020, GA, no. 649435)

${ }^{a}$ In Switzerland we asked if the country was *in * the EU

ket, too. Across the countries, a sizeable proportion ranging from about $17 \%$ in Greece and almost 30\% in France think it would make no difference, and between 14 and $24 \%$ of respondents are not sure.

Overall, we see considerable skepticism with reference to EU membership, which corroborates a general trend within the European citizenry identified by previous studies (McLaren 2007; Hooghe and Marks 2007; Leconte 2015). Against this backdrop, it is interesting to see how people in our eight countries would vote if there were a referendum on the EU membership of their country (in Switzerland we asked about joining). Results in Table 10.14 show once more that across countries, Switzerland prefers to stay outside and Greece would prefer to leave; there is a very slight preference for leaving in the UK much in line with the actual referendum from June 2016. Once more gaps are smaller in Italy and France than in Denmark, Germany and Poland, showing that the latter tend to be more Europhile, while citizens in the former countries lean more toward Euroskepticism.

This grouping is replicated when asking respondents if they believe that the UK should remain or leave the EU. Table 10.15 shows that a slightly higher proportion of UK respondents felt the UK should leave than those saying it should remain. The same applies to respondents from Switzerland, Greece, France and Italy, who corroborated once more Euroskeptic tendencies, whereas the Danes, Germans and Polish think the UK should stay. These citizens tend to defend the idea of the EU and the need to keep the countries within it. 
Table 10.14 Referendum on EU membership (in \%)

\begin{tabular}{lccccc}
\hline & Remain $^{a}$ & Leave $^{a}$ & Would not vote & Don't know & Total \\
\hline Denmark & 47.6 & 32.1 & 4.2 & 16.1 & 100 \\
France & 42.7 & 30.3 & 7.6 & 19.4 & 100 \\
Germany & 61.3 & 23.5 & 6.0 & 9.3 & 100 \\
Greece & 37.7 & 46.3 & 7.9 & 8.1 & 100 \\
Italy & 43.1 & 36.1 & 6.4 & 14.5 & 100 \\
Poland & 64.0 & 14.8 & 7.8 & 13.4 & 100 \\
Switzerland & $10.5^{\mathrm{a}}$ & $74.3^{\mathrm{a}}$ & $5.7^{\mathrm{a}}$ & $9.5^{\mathrm{a}}$ & 100 \\
UK $_{\text {Total }}^{4}$ & 44.3 & 45.2 & 3.7 & 6.8 & 100 \\
\hline
\end{tabular}

'If there was a referendum on your country's membership of the EU how would you vote?' Source: TransSOL (Horizon2020, GA, no. 649435)

${ }^{a}$ In Switzerland we asked about joining the EU

Table 10.15 Should the UK remain a member or leave the EU? (in \%)

\begin{tabular}{lcccc}
\hline & Remain & Leave & Don't know & Total \\
\hline Denmark & 45.1 & 34.5 & 20.4 & 100 \\
France & 30.3 & 46.6 & 23.1 & 100 \\
Germany & 51.7 & 35.7 & 12.6 & 100 \\
Greece & 32.2 & 51.7 & 16.1 & 100 \\
Italy & 39.8 & 43.2 & 17.0 & 100 \\
Poland & 59.0 & 19.5 & 21.5 & 100 \\
Switzerland & 26.3 & 55.1 & 18.7 & 100 \\
United Kingdom & 45.3 & 47.1 & 7.6 & 100 \\
Total & 41.1 & 41.7 & 17.2 & 100 \\
\hline
\end{tabular}

Source: TransSOL (Horizon2020, GA, no. 649435)

In Table 10.16 we look at the relationship between membership of the EU and fiscal solidarity. The results show that there is a clear relationship between both: respondents more favorable to EU membership are also more likely to support fiscal solidarity.

Finally, we move to a question that tackles more directly the affective or emotional dimension of EU identification, because respondents were encouraged to assess their attachment to the European Union as well as to other entities including the world/humanity, one's country and region and one's city. Table 10.17 indicates that the EU scores the lowest levels 
Table 10.16 Solidarity and support for EU membership (\% a good thing)

\begin{tabular}{lc}
\hline $\begin{array}{l}\text { Agreement with pooling } \\
\text { funds to help countries } \\
\text { in debt (see Table 10.4) }\end{array}$ & Supports EU membership \\
\hline Strongly disagree & \\
Disagree & 15.2 \\
Neither & 28.0 \\
Agree & 35.1 \\
Strongly agree & 55.5 \\
Don't know & 57.0 \\
Total & 24.0 \\
\hline
\end{tabular}

Source: TransSOL (Horizon2020, GA, no. 649435)

Table 10.17 Attachments (\% fairly and very attached)

\begin{tabular}{lccccc}
\hline & European Union & The world/humanity & Country & Region & City \\
\hline Denmark & 33.4 & 64.1 & 90.8 & 62.2 & 80.3 \\
France & 47.1 & 72.7 & 88.6 & 80.5 & 79.0 \\
Germany & 53.3 & 69.0 & 83.7 & 79.1 & 82.1 \\
Greece & 32.3 & 73.8 & 90.5 & 85.0 & 85.0 \\
Italy & 49.1 & 73.4 & 78.1 & 80.2 & 82.3 \\
Poland & 65.8 & 79.9 & 89.8 & 87.8 & 87.6 \\
Switzerland & 28.1 & 74.6 & 89.1 & 84.0 & 81.1 \\
United Kingdom & 40.1 & 67.7 & 82.5 & 75.8 & 79.7 \\
Total & 43.5 & 71.9 & 86.7 & 79.3 & 82.1 \\
\hline
\end{tabular}

'Please tell me how attached you feel to ...?'

Source: TransSOL (Horizon2020, GA, no. 649435)

of attachment compared to the other spatial entities. The strongest attachment to the EU is clearly in Poland, followed by Germany, Italy and France, then the UK, Denmark, Greece and Switzerland. When we compare the attachment to the EU with the instrumental assessment of the EU membership (Table 10.8), we see that the proportions of people who feel attached to the EU match clearly the rates of those respondents considering EU membership to be a good thing. In France and Italy, almost every second respondent feels attached to the EU, but this does not prevent them from assessing their country's membership of the EU more critically. In Denmark, the relation is inversed, because the feelings of attachment are less diffused as the impression that EU membership is 
Table 10.18 Solidarity and attachment to the EU (\% fairly and very attached)

\begin{tabular}{lc}
\hline $\begin{array}{l}\text { Agreement with pooling funds } \\
\text { to help countries in debt (see }\end{array}$ & Attached to the EU \\
Table 10.4) & \\
\hline Strongly disagree & 18.2 \\
Disagree & 31.2 \\
Neither & 43.5 \\
Agree & 59.0 \\
Strongly agree & 58.7 \\
Don't know & 30.6 \\
Total & 43.5 \\
\hline
\end{tabular}

Source: TransSOL (Horizon2020, GA, no. 649435)

good for their country. We thus see that people's feelings and instrumental reasonings converge, but not necessarily in all countries.

All these findings show that citizens identify with the European Union, even though these relations are nuanced. However, we should assume that citizens with a more developed European identity might be more supportive of the idea of European solidarity. In order to assess this assumption, it is necessary to measure the relationship between preferences for European solidarity and attachment to the European Union. For this purpose we use two questions introduced before: support for fiscal redistribution within the EU (see Table 10.4) and attachment to the EU (see Table 10.17). This allows us to have a look at the extent to which support for fiscal solidarity within the EU coincides with feelings of attachment to the EU. Table 10.18 shows that those who share the strongest feelings of attachment to the European Union are also those that are most likely to support the pooling of funds to help countries in debt.

\section{Understanding Solidarity as a Social Force: Preliminary Conclusions}

Solidarity is a pressing issue of our times. The various crises affecting the European Union since 2008 have increased the call for solidarity between the European people, especially when dealing with the consequences of the Great Recession and/or the welcoming of refugees fleeing from war, persecution and poverty. The evidence presented in this book paints a nuanced picture of solidarity within Europe. We found that a strong majority of respondents supports the attempts of the EU to help countries 
outside Europe in fighting poverty and promoting development; every second respondent reports having engaged in solidarity activities for people in their country, including donating money or time, protesting and engaging in voluntary associations; and European citizens strongly support solidarity-based (redistributive) public policies with almost threequarters considering the reduction of big income inequalities as an important goal.

However, our data revealed at the same time that solidarity is not universally and unconditionally granted. The analysis of the motives of people to support fiscal solidarity within the EU, for instance, shows that the largest group subscribes to the idea of reciprocity and deservingness. In this sense, our findings subscribe largely to those insights provided by previous research. The group of people with a universalist or cosmopolitan sense of solidarity are largely in the minority. For most people, solidarity is more strongly tied to specific groups or entities (Markovsky and Lawler 1994; Hunt and Benford 2004; Stets and McCaffree 2014), and very often solidarity is closely tied to the notion of citizenship (Miller 2000; Keating 2009). This is particularly evident when solidarity touches social rights and obligations, as, for instance, with regard to policies of redistribution at the national or European level. As our own data has shown, respondents prefer to restrict the access to social benefits to fellow citizens, to those working or paying taxes. And in regards to fiscal solidarity within the EU, citizens most strongly believe that solidarity should conform to norms of reciprocity and trustworthiness (see also Lengfeld et al. 2015; also Wheeless 1978; Thielemann 2003). Additionally, our results showed that those who share feelings of attachment to the European Union are also those that are most likely to support the pooling of funds to help countries in debt. These citizens seem to acknowledge that European citizenship is in place and that members of this community are thus expected to support each other.

In sum, citizens' views about fiscal solidarity within the EU tend to follow a rationale that is very similar to the one underlying public support of national welfare policies (Bowles and Gintis 2000; Oorschot 2006; León 2012). Additionally, these attitudes are not very distant from motives guiding civic and social solidarity within interpersonal relations and informal networks, because these solidarity relations are also governed by ideas of reciprocity, fairness, trustworthiness and deservingness (Markovsky and Lawler 1994; Oorschot 2000; Komter 2005; Molm et al. 2009). Solidarity 
seems to be patterned similarly across various reference groups, be that peers or neighbors, fellow citizens, Europeans or people outside Europe.

The findings of this book do not only provide important lessons about the rationale guiding solidarity at various levels of organization-the national, the European and the global. They have also given indications about the social and political factors inhibiting or limiting solidarity and thus about those groups within the population that are closer or more distant from practices and attitudes of solidarity. In this way, a number of lessons can be drawn from the national studies.

In the first instance, solidarity seems to follow a cumulative logic. Citizens actively supporting other people in their country are more probably engaged also in solidarity with people within the EU and beyond, while people who are more passive in regard to one reference group will be also probably be more inactive with respect also to the others (see Kiess et al. in this book). Hence, the difference between activity and inactivity seems to be more important than the target group to which solidarity is directed. However, this cumulative logic is certainly not universally applicable, particularly with respect to exclusive or antagonistic groups that mobilize their constituencies for their own sake and against others. Additionally, we have seen that solidarity across borders is less common within the European populations than solidarity practices within borders. However, our data indicate that solidarities are not necessarily exclusive and antagonistic. We might even hypothesize that most active people are engaged in multiple ways, even if these solidarities are patterned-in their proportions-along concentric circles of proximity and distance.

The analyses assembled in this book also give indications about those social and political factors that impact on solidarity disposition and practices. Among the main factors to be highlighted are the following. First, interpersonal trust seems to be an important precondition and resource explaining the commitment of citizens to supporting others. The importance of this factor has been highlighted in all chapters of this book. Solidarity is more probable when citizens consider the recipient of their help as trustworthy, thus testifying that norms of deservingness and reciprocity are at stake here, too (see also Wheeless 1978; Oorschot 2000; Brown and Ferries 2007). Second, religiosity influences solidarity as well, even though not all chapters testify to the importance of this factor for their countries. Religious people are more active in support of others than non-religious respondents, independent of the target group this support is 
directed at. As argued by others, religion plays a role not only because of the ethical claims it makes but also since we examine institutionalized forms of religiosity that imply collective forms of help and care (Abela 2004; Lichterman 2015).

Third, solidarity has a strong political component, not least because the idea of solidarity is part of the oratory of many social movements and their mobilization attempts (Giugni and Passy 2001; Hunt and Benford 2004; Scholz 2008). Additionally, we have been argued in this book that solidarity has a political dimension per se, since it is more often than not implicitly or explicitly linked to rights and obligations stipulated within a specific group. This assumption is corroborated by the national studies also in regard to forms of interpersonal solidarity. In fact, solidarity practices can be differentiated along the distinction between civic and political orientations (see Fernandez in this book). Additionally, respondents testifying that they have been engaged in practices of solidarity are more often interested in politics (see Maggini or Cinalli and Sanhueza in this book), are more involved in unconventional forms of participation (see Kalogeraki in this book) and/or are more active as newspaper readers (see Montgomery et al. in this book). Their practiced solidarity seems to be motivated also by a dissatisfaction with government policies toward the respective target group (see Kiess et al. in this book). Poland is an interesting exception, because analyses identify it as disaplying commitment to transnational solidarity that is not politically motivated (see Kurowska and Theiss in this book).

Fourth, in most countries, contacts with and attachments to the specific target groups (people with disabilities, the jobless, refugees) and identification with spatial entities (the nation, Europe) make a difference with respect to promoting solidarity practices. The British case illustrates that solidarity practices may be also unevenly distributed within the territory, with higher rates of support for various target groups in Scotland and Northern Ireland (see Montgomery et al. in this book).

Finally, we see that socio-demographic traits and social structural resources play a less consistent and important role, when compared to the previously discussed factors. While previous research has highlighted the importance of some of these factors, among them gender (Neill and Gidengil 2006), age and biographical availability (Beyerlein and Bergstrand 2013; Grasso 2014), education (Bauer et al. 2013; Grasso 2013) or occupational and class status (Wilson 2000), our own analyses do not draw a consistent picture. Age and gender do not play a consistent role across countries, although biographical availability seems to be relevant for volun- 
teering in Greece. Socio-economic status plays a role in various countries, but the relevant factors change from country to country. It is either higher education (Denmark, Germany and Poland), income and occupational status (Denmark and Poland) or the respondents identifying with the middle classes (Italy) that matter in explaining solidarity practices.

These inconclusive findings are probably linked to the design of our analyses, since a more focused study on specific forms of solidarity practices (e.g., donating money or attending protest events for specific target groups) might have identified more specific social profiles of engaged people. However, the aim of our analyses was to measure more general dispositions and practices of solidarity. In this regard, the lesser relevance of socio-demographic and social structural traits is telling in itself. Solidarity practices are not restricted to specific strata of the population but tied to different groups within society (Giugni and Grasso 2015).

What do we learn from these findings for making sense of the prospects of European solidarity? On the one hand, we have to expect that solidarity across borders is unlikely to be prioritized by European citizens. And this seems to be particularly true for European solidarity. This has to do with the fact that the feelings of attachment and identification with Europe and the European Union are less developed than those to one's own country, region or town. Europeans tend to be more engaged with respect to fellow citizens and people in their proximity, and this also means that practices of solidarity targeting other EU countries are secondary. To this, we have to add that the discontent with the European Union seems to translate into a weaker disposition to support redistribution between states, and possibly also between citizens. The rise of Euroskeptical sentiments in the population (McLaren 2007; Hooghe and Marks 2007; Leconte 2015) and the growing importance of populist parties rallying for nationalist and xenophobic agendas (Taggart 2004; Krouwel and Abts 2007; Kriesi and Pappas 2015) have the potential to diminish the prospects of European solidarity within the citizenry.

However, against these negative views we argue that on balance there is more hope and that there is room for a further development of European solidarity (see also Börner 2014; Gerhards et al. 2016). The lessons drawn from our analyses seem to boil down to one major proposition. If European citizens privilege solidarity with fellow citizens, and if their solidarity is conditional on the active involvement of the targeted recipients in a relation of trust and reciprocity, then the idea of social citizenship becomes a turntable for the development of European solidarity. So far, European citizens claiming their social rights are referred back to their country of residence, 
since, within the EU, social citizenship is tied back to the nation-state. Truly European measures of redistribution are needed to bolster the idea of a European social citizenship, such as redistributive programs to which all European citizens contribute and from which they receive support in times of trouble. The reservation which citizens voice against redistributive measures among European member states may just reflect a general feeling that there is not yet a fair system of rules in place that balances the mutual rights and obligations of the European people within the EU. The European Union is not yet an accomplished political community establishing and guaranteeing common social rights and obligations. The development of social rights and social citizenship, as widely discussed in the public sphere (Eder and Giessen 2001; Schmitter and Bauer 2001; Ferrera 2004; Keating 2009; Ross and Borgmann-Prebil 2010), could be an important instrument to increasingly develop and promote the readiness of citizens to support other European citizens-through either interpersonal help or public policies of redistribution moving forward into the future.

\section{REFERENCES}

Abela, A. M. (2004). Solidarity and Religion in the European Union: A Comparative Sociological Perspective. In P. Xuereb (Ed.), The Value(s) of a Constitution for Europe (pp. 71-101). Malta: European Documentation and Research Centre.

Anderson, C. J., \& Reichert, M. S. (1996). Economic Benefits and Support for Membership in the EU: A Cross-National Analysis. Journal of Public Policy, 15(3), 231-249.

Anheier, H. K., \& Salamon, L. M. (1999). Volunteering in Cross-National Perspective: Initial Comparisons. Law and Contemporary Problems, 62, 43-66.

Bauer, T. K., Bredtmann, J., \& Schmidt, C. M. (2013). Time vs. Money - The Supply of Voluntary Labor and Charitable Donations Across Europe. European Journal of Political Economy, 32, 80-94.

Beyerlein, K., \& Bergstrand, K. (2013). Biographical Availability. In D. A. Snow, D. D. Porta, B. Klandermans, \& D. McAdam (Eds.), The Wiley-Blackwell Encyclopedia of Social and Political Movements (pp. 137-138). New York: Wiley-Blackwell.

Blekesaune, M., \& Quadagno, J. (2003). Public Attitudes Toward Welfare State Policies: A Comparative Analysis of 24 Countries. European Sociological Review, $19(5), 415-427$.

Börner, S. (2014). From National to European Solidarity? The Negotiation of Redistributive Spaces. In S. Börner \& M. Eigmüller (Eds.), European 
Integration, Processes of Change and the National Experience (pp. 166-188). Basingstoke: Palgrave Macmillan.

Bowles, S., \& Gintis, H. (2000). Reciprocity, Self-Interest, and the Welfare State. Nordic Journal of Political Economy, 26, 33-53.

Brown, E., \& Ferries, J. M. (2007). Social Capital and Philanthropy: An Analysis of the Impact of Social Capital on Individual Giving and Volunteering. Nonprofit and Voluntary Sector Quarterly, 36(1), 85-99.

Burgoon, B. (2014). Immigration, Integration, and Support for Redistribution in Europe. World Politics, 66(3), 365-405.

Eder, K., \& Giessen, B. (2001). Conclusions: Citizenship and the Making of a European Society - From the Political to the Social Integration of Europe. In K. Eder \& B. Giessen (Eds.), European Citizenship Between National Legacies and Postnational Projects (pp. 245-269). Oxford: Oxford University Press.

Evangelinidis, A. (2016). The Greek State's Response to the Refugee Crisis and the Solidarity Movement. Contemporary Southeastern Europe, 3(1), 32-36.

Ferrera, M. (2004). Social Citizenship in the European Union. Toward a Spatial Reconfiguration? In C. K. Ansell \& G. di Palma (Eds.), Restructuring Territoriality. Europe and the United States Compared (pp. 90-121). Cambridge: Cambridge University Press.

Gang, I. N., Rivera-Batiz, F. L., \& Yun, M.-S. (2013). Economic Strain, Education and Attitudes Towards Foreigners in the European Union. Review of International Economics, 21(2), 177-190.

Gerhards, J., Lengfeld, H., \& Häuberer, J. (2016). Do European Citizens Support the Idea of a European Welfare State? Evidence from a Comparative Survey Conducted in Three EU Member States. International Sociology, 31(6), 677-700.

Giugni, M., \& Grasso, M. T. (2015). Environmental Movements in Advanced Industrial Democracies: Heterogeneity, Transformation, and Institutionalization. Annual Review of Environment and Resources, 40, 337-361.

Giugni, M., \& Grasso, M. T. (2016). How Civil Society Actors Responded to the Economic Crisis: The Interaction of Material Deprivation and Perceptions of Political Opportunity Structures. Politics \& Policy, 44(3), 447-472.

Giugni, M., \& Passy, F. (Eds.). (2001). Political Altruism? Solidarity Movements in International Perspective. Lanham, MD: Rowman \& Littlefield.

Grasso, M. T. (2011). Political Participation in Western Europe. D.Phil. Thesis, Nuffield College, University of Oxford.

Grasso, M. T. (2013). The Differential Impact of Education on Young People's Political Activism: Comparing Italy and the United Kingdom. Comparative Sociology, 12(1), 1-30.

Grasso, M. T. (2014). Age-Period-Cohort Analysis in a Comparative Context: Political Generations and Political Participation Repertoires. Electoral Studies, $33,63-76$. 
Grasso, M. T. (2016). Generations, Political Participation and Social Change in Western Europe. London: Routledge.

Grasso, M. T., \& Giugni, M. (2016). Protest Participation and Economic Crisis: The Conditioning Role of Political Opportunities. European Journal of Political Research, 55(4), 663-680.

Grasso, M. T., Farrall, S., Gray, E., Hay, C., \& Jennings, W. (2017). Thatcher's Children, Blair's Babies, Political Socialisation and Trickle-down Value-change: An Age, Period and Cohort Analysis. British Journal of Political Science. https://doi.org/10.1017/S0007123416000375.

Green-Pedersen, C., \& Otjes, S. (2017). A Hot Topic? Immigration on the Agenda in Western Europe. Party Politics. Online first, Published August 31, 2017. https://doi.org/10.1177/1354068817728211.

Guerra, S., \& McLaren, L. M. (2016). Public Opinion and the European Union. In M. Cini \& N. P.-S. Borragán (Eds.), European Union Politics (5th ed., pp. 352-364). Oxford: Oxford University Press.

Hafner Fink, M. (2012). Political Participation, Democratisation and Citizens' Values in Europe. Teorija in Praksa, 49(3), 544-565.

Hooghe, L., \& Marks, G. (2007). Sources of Euroscepticism. Acta Politica, 42(2), $119-127$.

Hunt, S. A., \& Benford, R. D. (2004). Collective Identity, Solidarity, and Commitment. In D. A. Snow, S. A. Soule, \& H. Kriesi (Eds.), The Blackwell Companion to Social Movements (pp. 433-457). Oxford: Blackwell.

Keating, M. (2009). Social Citizenship, Solidarity and Welfare in Regionalized and Plurinational States. Citizenship Studies, 13(5), 501-513.

Komter, A. E. (2005). Social Solidarity and the Gift. Cambridge: Cambridge University Press.

Kriesi, H., \& Pappas, T. S. (Eds.). (2015). European Populism in the Shadow of the Great Recession. Colchester: ECPR Press.

Krouwel, A., \& Abts, K. (2007). Varieties of Euroscepticism and Populist Mobilization: Transforming Attitudes from Mild Euroscepticism to Harsh Eurocynicism. Acta Politica, 42(2), 252-270.

Leconte, C. (2015). From Pathology to Mainstream Phenomenon: Reviewing the Euroscepticism Debate in Research and Theory. International Political Science Review, 36(3), 250-263.

Lengfeld, H., Schmidt, S., \& Häuberer, J. (2015, April 1). Is There a European Solidarity? Attitudes Towards Fiscal Assistance for Debt-Ridden European Union Member States. Report No. 67, University of Leipzig.

León, F. J. (2012). Reciprocity and Public Support for the Redistributive Role of the State. Journal of European Social Policy, 22(2), 198-215.

Lichterman, P. (2015). Religion and Social Solidarity. A Pragmatist Approach. In L. Hustinx, J. von Essen, J. Haers, \& S. Mels (Eds.), Religion and Volunteering. 
Complex, Contested and Ambiguous Relationships (pp. 241-261). Cham: Springer.

Markovsky, B., \& Lawler, E. J. (1994). A New Theory of Group Solidarity. In B. Markovsky, K. Heimer, \& J. O'Brien (Eds.), Advances in Group Processes (pp. 113-137). Greenwich, CT: JAI Press.

McLaren, L. (2007). Explaining Mass-level Euroscepticism: Identity, Interests, and Institutional Distrust. Acta Politica, 42(2), 233-251.

Miller, D. (2000). Citizenship and National Identity. Cambridge: Polity Press.

Molm, L. D., Collett, J. L., \& Schaefer, D. R. (2009). Building Solidarity Through Generalized Exchange: A Theory of Reciprocity. American Journal of Sociology, $113(1), 205-242$.

Neill, B., \& Gidengil, E. (Eds.). (2006). Gender and Social Capital. New York: Routledge.

van Oorschot, W. (2000). Who Should Get What, and Why? On Deservingness Criteria and the Conditionality of Solidarity Among the Public. Policy o Politics, 28(1), 33-48.

van Oorschot, W. (2006). Making the Difference in Social Europe: Deservingness Perceptions Among Citizens of European Welfare States. Journal of European Social Policy, 16(1), 23-42.

van Oorschot, W., Arts, W., \& Gelissen, J. (2006). Social Capital in Europe. Measurement and Social and Regional Distribution of a Multifaceted Phenomenon. Acta Sociologica, XLIX, 149-167.

Ross, M., \& Borgmann-Prebil, Y. (Eds.). (2010). Promoting Solidarity in the European Union. Oxford: Oxford University Press.

Schmitter, P. C., \& Bauer, M. W. (2001). A (Modest) Proposal for Expanding Social Citizenship in the European Union. Journal of European Social Policy, $11(1), 55-65$.

Scholz, S. J. (2008). Political Solidarity. University Park, PA: Penn State University Press.

van Setten, M., Scheepers, P., \& Lubbers, M. (2017). Support for Restrictive Immigration Policies in the European Union 2002-2013: The Impact of Economic Strain and Ethnic Threat for Vulnerable Economic Groups. European Societies, 19(4), 440-465.

Sotiropoulos, D. A., \& Bourikos, D. (2014). Economic Crisis, Social Solidarity and the Voluntary Sector in Greece. Journal of Power, Politics \& Governance, 2(2), 33-53.

Stets, J. E., \& McCaffree, K. (2014). Linking Morality, Altruism, and Social Solidarity Using Identity Theory. In V. Jeffries (Ed.), The Palgrave Handbook of Altruism, Morality, and Social Solidarity (pp. 333-351). New York: Palgrave Macmillan.

Svallfors, S. (1997). Worlds of Welfare and Attitudes to Redistribution: A Comparison of Eight Western Nations. European Journal of Sociology, 13(3), 283-304. 
Taggart, P. (2004). Populism and Representative Politics in Contemporary Europe. Journal of Political Ideologies, 9(3), 269-288.

Thielemann, E. R. (2003). Between Interests and Norms: Explaining BurdenSharing in the European Union. Journal of Refugee Studies, 16(3), 253-273.

Wheeless, L. R. (1978). A Follow-up Study of the Relationship Among Trust, Disclosure, and Interpersonal Solidarity. Human Communication Research, $4(2), 143-157$.

Wilson, J. (2000). Volunteering. Annual Review of Sociology, 26, 215-240.

Open Access This chapter is licensed under the terms of the Creative Commons Attribution 4.0 International License (http://creativecommons.org/licenses/ by $/ 4.0 /)$, which permits use, sharing, adaptation, distribution and reproduction in any medium or format, as long as you give appropriate credit to the original author(s) and the source, provide a link to the Creative Commons license and indicate if changes were made.

The images or other third party material in this chapter are included in the chapter's Creative Commons license, unless indicated otherwise in a credit line to the material. If material is not included in the chapter's Creative Commons license and your intended use is not permitted by statutory regulation or exceeds the permitted use, you will need to obtain permission directly from the copyright holder.

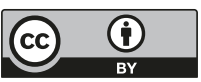

